УДК 94(477) «1918»

ТКАЧУК П.П.

https://orcid.org/0000-0002-7190-7887

https://doi.org/10.33577/2313-5603.31.2019.112-123

\title{
ВІЙСЬКОВІ РЕФОРМИ ГЕТЬМАНА ПАВЛА СКОРОПАДСЬКОГО У КОНТЕКСТІ ДЕРЖАВОТВОРЧИХ ПРОЦЕСІВ В УКРАЇНІ (квітень - грудень 1918 р.)
}

Проаналізовані військові реформи гетьмана Павла Скоропадського в контексті державотворчих процесів в Українській державі. Відзначено, що можливості для військового будівництва обмежувалися німецькою окупаційною владою, а також пропозицією федерування України з іншими частинами небільшовицької Росії, яку сповідував кадетсько-октябристський уряд Української Держави. Зазначено, що гетьман взяв курс на створення регулярної боєздатної армії, для чого залучив досвідчених генералів, адміралів, старших офіцерів колишньої царської армії, які виявили бажання служити Україні. Доведено, що за Гетьманату були закладені основи для розвитку українських Збройних Сил, які за своєю організацією, структурою, командними кадрами, озброєнням і тактикою виходили на рівень 3 арміями європейських держав.

Ключові слова: Павло Скоропадський, Українська держава, військові реформи, Збройні сили.

Актуальність проблеми. Збройні Сили завжди були вирішальним фактором існування державних утворень, особливо в умовах зовнішньої агресії. Сьогодні, коли триває російська агресія на Сході нашої держави варто звернутись до історичного минулого, зокрема до періоду Української Держави часів гетьмана Павла Скоропадського. Цей період став показовим у розбудові регулярного національного війська. Досвідчений військовик, до революції командир 34-го армійського корпусу, почесний отаман Вільного козацтва, гетьман Павло Скоропадський, прийшовши до влади 29 квітня 1918 р., зосередив основну увагу на формуванні власної регулярної армії.

Метою статmі є аналіз військових реформ того важкого періоду української історії. Розбудовувати Збройні Сили П. Скоропадському доводилося у складних геополітичних умовах. Німецькі окупанти, вважаючи Гетьманат тимчасовою владою, категорично виступали проти його планів сформувати масову армію на основі загальної

Ткачук Павло Петрович, доктор історичних наук, професор, Заслужений працівник освіти України, начальник Національної академії сухопутних військ імені гетьмана Петра Сагайдачного, м. Львів.

(C) Ткачук П.П., 2019 
військової повинності. Власне, на думку начальника штабу групи німецьких військ «Київ» генерала В. Гренера, український уряд мав насамперед підтримувати німецькі збройні сили у заготівлі зерна і продуктів. Цим, зокрема, займалися німецькі консульські установи у Києві, Харкові, Катеринославі, Одесі, Миколаєві. Обмежувала гетьманське правління й Австро-Угорщина, до окупаційної зони якої відійшла частина Волині, Подільська, Херсонська i Катеринославська губернії. Відтак гетьманові довелося всіляко маневрувати (Литвин, 2003:260-268).

Виклад основного матеріалу. Ініціативи влади також стримувала російська імперська спадщина, яка регенерувалася в правничій практиці, пресі, церковно-релігійному житті, використанні старих кадрів, толеруванні політично різнобарвної російської еміграції. Щоб прихилити на свій бік загалом небідне офіцерство російської армії, яке осіло на Наддніпрянщині, гетьман вже у першій своїй «Грамоті до всього українського народу» оголосив недоторканність приватної власності, свободу торгівлі й підприємництва, відновлення основ культури і цивілізації (Україна: хроніка XX століття: $177,178)$. Водночас прагнув заручитися підтримкою духовенства Православної церкви, яке традиційно мало капеланів у військових частинах (Ульяновський, 1997:60-75). Оновлено текст військової присяги (один варіант - для сповідуючих християнство, другий для інших). Ухвалено «Закон про військову підсудність». Вживалися різні заходи, які мали зробити службу в армії привабливою i почесною.

Перед військовим відомством гетьман П. Скоропадський визначив завдання створити 300-тисячну регулярну армію (Brucki, 2000:599). Однак, командування німецької окупаційної армії дозволило гетьманові мати військову формацію не більше 65 тис. вояків. У цій ситуації П. Скоропадський вирішив укомплектувати свої війська вишколеними офіцерськими кадрами, тобто мати кадрову армію, яка могла б у короткий термін розгорнутися у заплановану за мобілізацією. Отже, Військове міністерство розгорнуло у травні червні процес комплектування армії командним складом полків $\mathrm{i}$ дивізій восьми армійських корпусів: Волинського, Подільського, Херсонського, Київського, Чернігівського, Полтавського, Харківського і Катеринославського. Гетьман планував мати армію мирного часу, яка потребувала 175 генералів і 14930 штаб- і обер-офіцерів, 3 них не менше 500 офіцерів Генерального штабу (Монкевич, 1995:67-112). 
Кожен корпус мав складатися 3 двох піхотних дивізій, двох бригад польових гармат, однієї бригади власних гармат, одного корпусу кінного полку, чотирьох автопанцерних і радіотелеграфічних сотень, повітряного полку, двох залізничних сотень, технічного i санітарних куренів. Піхотна дивізія мала складатися 3 трьох піхотних полків, полк - 3 трьох куренів, курінь - 3 трьох стрілецьких сотень і сотні скорострілів. Артилерійська бригада мала складатися 3 трьох полків, кожен полк - 3 трьох батарей (Якимович, 1996:96-98). Чимала увага приділялася відродженню козацьких військових традицій. 24 липня запроваджено Закон про обов'язковість військової повинності (Задунайський, 2003:98-104).

«Гетьман намагався організувати спочатку невелику, але цілком певну армію, - зазначав діаспорний історик Василь Верига. - Як основа іiі мав бути сформований надійний офіцерський корпус 3 тодішніх, дуже старанно вибраних, українських і російських офіцерів. Але на перешкоді стали німці... Єдине, чого вдалося добитися Гетьманові - це дозвіл на сформування однієї пішої т.зв. Сердюцької дивізії із добровольців» (близько п'ять тисяч вояків. - $\boldsymbol{A m m . )}$ (Верига, 1998:335). Обходячи перепони або знаходячи компроміси 3 німцями, П. Скоропадський розгортав нове військове будівництво 3 утворення вищих структур українського війська, зокрема артилерії.

Уже 2 - 10 травня 1918 р. було сформовано Раду міністрів на чолі з головою (отаманом) Федором Лизогубом, зокрема й Військове міністерство, яке виконувало головне завдання - організацію української армії. Підбираючи кандидатуру на посаду військового міністра, П. Скоропадський запропонував іï відомому артилеристу генералові Василю Кирею, який, щоправда, відмовився. Кандидатура генерала В. Дашкевича-Горбацького викликала спротив німців. Отож, міністром став українець з Чернігівщини, син священика, бойовий генерал, командувач армії в роки Першої світової війни Олександр Рогоза (1858 - 1919).

До складу Міністерства входило Головне Артилерійське Управління (ГАУ), функції якого були подібними до згадуваного вже ГАУ російської армії. Його очолив 63-річний генерал-хорунжий Іван Значко-Яворський, уродженець Полтави, вихованець Чугуївського юнкерського училища та Академії Генерального штабу, кавалер 3олотої Георгієвської зброї. Під його керівництвом діяли навчальні, технічні та господарські формації артилерійського відомства. Йому 
підпорядковувалися відділи: загальний (полковник ГогольЯновський), ручної зброї (полковник Вакар), гарматний (полковник Християнович), амуніції і набоїв (полковник С. Лукашевич), хімічний (полковник Володимир Сінклер) (Монкевич, 1995:67-112).

У липні 1918 р. ГАУ очолив 44-річний генерал Микола Синєоків, високоосвічений артилерист. Він закінчив Донський кадетський корпус, артучилище і Михайлівську артакадемію, до призначення на посаду був начальником артилерії 1-го Волинського корпусу. 3 жовтня 1918 р. - генерал-значковий (генерал-лейтенант). У березні 1919 р. перейшов до Добрармії Денікіна, згодом перебував в еміграції (помер у 1934 р.) (Волков, 2002:514).

Вишколом кадрів займалася Головна Шкільна Управа, якій підпорядковувалися військові школи, училища, кадетські корпуси всіх родів зброї. До ії складу, зокрема, входив Навчальний відділ $з$ підвідділом гарматних шкіл, який влітку 1918 р. очолив уже згаданий генерал І. Значко-Яворський. При Головній Шкільній Управі діяла Комісія з утворення військових шкіл в Україні під керівництвом генерала М. Юнаківа. До організаційно-методичної роботи в комісії генерал залучив досвідчених генералів: А. Нілуса, С. Дельвіга, Д. Промтова, О. Попова, В. Кирея. Саме їх зусиллями були створені або відновили навчання кадетські корпуси у Києві, Полтаві, Одесі, Сумах і Миколаєві, Київська юнацька гарматна школа (начальник Д. Промтов), Одеська юнацька гарматна школа (А. Нілус), Старшинська артилерійська школа в Дарниці під Києвом (О. Попов) та запроектовано Львівську юнацьку гарматну школу (Монкевич, 1995:77,78).

Потужні сухопутні сили армії Української держави слід було укомплектувати командними кадрами. Їх брак відчувався особливо у нижній ланці, що потребувало створення або відродження системи військової освіти, занедбаної в добу Центральної Ради. Саме 3 цією метою декретом гетьмана від 17 червня 1918 р. при Військовому міністерстві була сформована спеціальна «Комісія по утворенню постійних військових шкіл та Академії України». Її очолив досвідчений генеральний значковий (генерал-лейтенант) Микола Юнаків. Уродженець Чугуєва, син генерала російської армії отримав блискучу освіту: закінчив кадетський корпус, 1-ше Павловське училище, Миколаївську академію Генштабу, служив у елітних частинах, був професором Академії, автором воєнно-історичних праць, а в роки Першої світової війни командував 4-ю армією (Литвин, Науменко, 2007:217). 
До складу нової комісії увійшли сорок генералів і полковників Генерального штабу, зокрема генерали Сергій Дельвіг, Олександр Остафіїв, Василь Кирей, Дмитро Промов, Іван Значко-Яворський, Варфоломій Свтимович, Всеволод Петрів, Леонтій Родцевич, а також колишні начальники військових училищ і кадетських корпусів Свген Сімашкевич, Тарас Протазанов, Борис Гернгрос, Михайло Клінгенберг та ін. Вказана комісія діяла спільно з Головною Шкільною Управою, збереженою від часів Центральної Ради (Кривизюк, 2006:46).

«Для майбутньої армії слід було утворити відповідні школи, згадував П. Скоропадський. - Як це не було важко, але ми сподівалися утворити п'ять шкіл. На посаду головного начальника військово-освітньої справи я запросив професора Миколаївської військової академії генерала М. Юнаківа» (Скоропадський, 1995:179, 180). Але зусиллями Головної Шкільної Управи та Комісії генерала Юнаківа план гетьмана перевершили: було створено десять Юнацьких шкіл. Зауважимо, що в структурі управи функціонували відділи піхотних, кінних, гарматних та інших шкіл, які творили мережу військових навчальних закладів Сухопутних військ армії Української держави. Зокрема, розгорнув діяльність відділ піших шкіл.

Головна Шкільна Управа, підпорядкована Військовому міністерству у тісній взаємодії із вказаною Комісією генерала М. Юнаківа утворила мережу військових шкіл для підготовки командних кадрів Сухопутних військ армії Української держави. Відділ піших шкіл під керівництвом полковника Генштабу Всеволода Петріва утворив так звані Юнацькі школи: 1-шу Київську ім. Б. Хмельницького (начальник - генерал Йосип Богданович); 2-гу Київську (генерал Олексій Максимів); Полтавську (генерал Микола Анісімов); Одеську (генерал Олександр Кислов); Чугуївську (генерал Тарас Протазанов). Житомирську і Львівську планувалося відкрити згодом. Відділ гарматних шкіл полковника Івана Значко-Яворського опікувався Юнацькими школами: Київською (начальник генерал Дмитро Промтов); Одеською, утвореною на базі заснованого 1914 р. Сергієвського артилерійського училища на чолі 3 колишнім начальником училища генералом Андрієм Нілусом; Львівською (в проекті). Крім того, Головній Шкільній Управі підпорядковувалися: Єлисаветградська кінна Юнацька школа (полковник О. Петренко); Київська інженерна (генерал Е. Ельснер) (Скоропадський, 1995:179, 180). 
Усвідомлюючи надзвичайно важливу роль кадетських корпусів у процесі виховання і вишколу майбутніх командирів, П. Скоропадський у своїх спогадах відзначав: «Одним з моїх перших наказів було відновлення кадетських корпусів... Кадетські корпуси я повернув у лоно військового міністерства» (Скоропадський, 1995:179). Зазначимо, що одним із перших актів Тимчасового уряду Росії 1917 р. їх передали у підпорядкування Міністерства освіти, що призвело до їх занепаду. Цікаво, що утворені 1938 р. артилерійські спецшколи (всього 16), в яких вихованці навчалися за програмою 8 - 10 класів й скеровувалися в артучилища, теж були спочатку підпорядковані Наркомосу СРСР. Лише 1946 р. вони переведені під юрисдикцію Міністерства оборони, що радикально поліпшило їх матеріальнотехнічну базу і кадрове забезпечення (Kiм, 6, 7).

В Українській державі було відновлено функціонування кадетських корпусів як важливої ланки у системі підготовки командних кадрів для Сухопутних військ армії. Зазвичай їх створювали на базі існуючих в Україні навчальних закладів. Відтак, улітку 1918 р. терміново відкрили п'ять кадетських корпусів, на чолі яких здебільшого стали колишні начальники подібних закладів: Київський (генерал Євген Сімашкевич); Полтавський (генерал Микола Антонов); Одеський (генерал Микола Родцевич); Сумський (генерал Андрій Саранчов); Миколаївський (проект).

Кадетські корпуси були повністю укомплектовані офіцерським і викладацьким складом й частково - кадетами вже до кінця 1918 р. (Скоропадський, 1995:180). Важливе місце в системі підготовки командних кадрів займала заснована у Києві влітку 1918 р. Інструкторська школа старшин, в якій передбачалося вдосконалювати чи підвищувати кваліфікацію командирів у перспективі - їх використання на вищих посадах Сухопутних військ. Її очолив 42-річний генерал-майор Олексій Максимів, переведений з посади начальника 2-ї Київської Юнацької піхотної школи. На відміну від інших військових навчальних закладів, Інструкторська школа прийняла до пішого куреня та кулеметних, кінних, інженерних сотень і гарматної батареї разом 1300 старшин. 6 серпня 1918 р. школа здійснила перший випуск 283 старшин, які були призначені на командирські посади: у 3-й Херсонський армійський корпус - 55, в 5-й Чернігівський - 58, 6-й Полтавський - 57, 7-й Харківський - 56 і у 8-й Катеринославський - 57 старшин. Після другого випуску Школи 5 вересня у піхотні частини скерували 440 старшин, у кулеметні - 54, 
інженерні - 20, гарматні - 52 і в кінноту - 55 старшин (Монкевич, 1995:78, 79). Зауважимо, що в цю та інші зразково-інструкторські частини П. Скоропадський зобов'язав прийти офіцерів і понадстрокових унтер-офіцерів російської армії та недавніх юнкерів військових шкіл у віці до 35 років; старшим за віком дозволялося вступати до зразково-інструкторських частин добровільно (Державний вістник, 1918:1).

Відповідно до планів гетьмана П. Скоропадського 29 жовтня 1918 р. у Києві відкрито державну Військову академію з трирічним курсом навчання. Ії начальником призначено авторитетного військового діяча 48-річного генерала Миколу Юнаківа. На початку листопада 1918 р. оголосили прийом у Юнацькі школи молодих людей до 25 років із середньою освітою або випускників кадетських корпусів та в інші навчальні заклади Української держави. Але цей процес зупинило антигетьманське повстання під керівництвом Директорії УНР.

Згідно з наказом гетьмана П. Скоропадського у травні 1918 р. створено комісію для опрацювання штатів військових частин армії Української держави під головуванням Начальника Генерального штабу генерала О. Сливинського. До іiі складу ввійшла група досвідчених генералів (С. Дельвіг, В. Сінклер, О. Акерман, Д. Альтфатер, Ф. Колодій), яка розробила організаційну структуру артилерії та штати їі частин і підрозділів (ЦДАВО Украӥни, ф. 1074, on. 2, сnр. 7, арк. 37a). В основу організації артилерії покладено структуру, яка існувала в російській армії, з деякими змінами: враховано досвід світової війни та реальні можливості. Зокрема, артилерія за видами поділялася на польову, гірську і кінну. Найчисленнішою була польова артилерія, яка входила до складу піхотних дивізій і армійських корпусів (84 гарматних полки), яка, у свою чергу, ділилася на легку, важку і мортирну. Залежно від організаційного підпорядкування артилерія поділялася на армійську, корпусну і дивізійну (Кравчук, 1997:132). Зауважимо, що пізніше, в 1930-х роках, в арміях з'явилася ще й полкова та батальйонна артилерія.

Координувало цю важливу роботу Управління Головного інспектора артилерії на чолі з генералом-значковим Сергієм Дельвігом, яке підпорядковувалося Начальникові Генерального штабу. Головний інспектор артилерії у тісній співпраці з Управою персонального складу Головного штабу (начальник - військовий старшина, підполковник Микола Удовиченко) насамперед укомплектував свій 
апарат управління, командний склад армійської, корпусної і дивізійної артилерії високоосвіченими здібними старшинами і генералами 3 бойовим досвідом. Зокрема, всі вісім начальників артилерії корпусів були генералами, шестеро 3 них - М. Синєоків, I. Пащенко, М. Данилович, С. Лукашевич, П. Деревицький, С. Пащенко закінчили кадетські корпуси, артучилища, артакадемії, двоє В. Добровольський та І. Жуків - вищу освіту здобули в Офіцерській артшколі. В роки Першої світової війни на фронті командували гарматними полками, бригадами. Дві третини з них були українцями.

Зокрема, високий фаховий рівень демонстрували брати Іван i Євген Пащенки, перший - начальник артилерії 2-го Подільського корпусу, а другий - 6-го Полтавського. Вони народилися на Полтавщині й походили зі старовинної козацької родини. Військову освіту здобули у Полтавському Петровському кадетському корпусі, Михайлівському артучилищі і Михайлівській артилерійській академії в Петербурзі. В роки Першої світової війни командували гарматними бригадами на Південно-Західному фронті. За бойові заслуги відзначені багатьма нагородами. Генерали були щирими українцями, активно працювали у період формування артилерії своїх корпусів. На жаль, їхня плідна праця обірвалася наприкінці 1918 р. 3 приходом до влади Директорії, яка повторила помилки Центральної Ради стосовно «старих» кадрів. Генералів змусили покинути службу й згодом емігрувати (Литвин, Науменко, 2007:153, 154).

Високоосвіченими, 3 багатим фронтовим досвідом були всі 24 командири гарматних бригад корпусної і дивізійної артилерії, 3 них у ранзі генералів - 15, а решта - полковники. Військову освіту в обсязі кадетського корпусу, артилерійського або військового училища та артакадемії мали 15 комбригів, шестеро закінчили Офіцерську артшколу. Таким чином, 21 артилерійський командир мав вищу військову фахову освіту. На посади командирів гарматних полків, запланованих для формування, підібрано й призначено здібних старшин у званні полковник. Серед них було чимало діячів українського руху в російській армії.

Висновки. Отже, на відміну від Центральної Ради гетьману П. Скоропадському попри опір німецької окупаційної влади вдалося від самого початку державотворення взяти курс на створення регулярної боєздатної армії, на засадах плановості, організації зверху відповідно до опрацьованої концепції, структури і штатів. У перші ж місяці до військового будівництва залучено близько 300 генералів i адміралів, офіцерів Генерального штабу колишньої російської армії, 
які мали добру військову освіту, фронтовий досвід кількох війн. Завдяки відкриттю кадетських корпусів і військових училищ армія мала можливість поповнювати командирські кадри. Були створені умови для формування артилерійських полків і бригад. Цей процес проходив під керівництвом чіткої системи управління артилерією від Головного інспекторату артилерії Збройних сил до командирів полків і окремих дивізіонів.

24 липня 1918 р. П. Скоропадський і його уряд ухвалили розроблений Генеральним штабом за участю досвідчених генералів $\mathrm{i}$ полковників Генштабу О. Сливинського, О. Галкіна, М. Какуріна, Є. Мішковського, С. Дельвіга, В. Сінклера, М. Юнаківа, В. Петріва генеральний план організації армії Української держави, який доповнено 6 вересня після таємної зустрічі Скоропадського $з$ імператором Вільгельмом II у Берліні. Українська армія мала бути доведена до 300 тис. козаків і складатися з восьми армійських корпусів. У кожному з них мало бути дві піхотні, одна кінна дивізії та три гарматні бригади й окремий гарматний полк. До служби в армії залучалося 175 генералів, близько 45 тис. старшин, зокрема 500 старшин Генерального штабу (Крип'якевич, Гнатевич, Стефанів, 1992:426). Тоді ж у Берліні гетьману дозволено перебрати Чорноморський флот і приєднати Крим.

Водночас планувалося до листопада укомплектувати всі частини старшинським і підстаршинським складом, а 315 листопада здійснити перший призов 85 тис. добровольців. До березня 1919 р. передбачали мобілізувати ще 79 тис. і невдовзі довести чисельність армії до 300 тис. козаків, що гарантувало Українській державі повну безпеку (на ці заходи уряд виділяв 1 млрд 254 млн карбованців) (Крип'якевич, Гнатевич, Стефанів, 1992:426). Щодо оснащення зброєю, бойовою технікою та усім необхідним, то проблем майже не було: російські війська Південно-Західного і Румунського фронтів залишили в Україні багато озброєння і військового майна в місцях постійної дислокації.

Таким чином, гетьман П. Скоропадський розгорнув активне військове будівництво, навіть попри несприятливу геополітичну ситуацію. Виступ Директорії проти Гетьманату восени 1918 р. призупинив військову, аграрну та інші реформи, започатковані П. Скоропадським та його урядом. Гетьманські військові реформи частково впровадили опоненти навесні 1919 р. «Ясновельможний пан гетьман всієї України» (офіційний титул П. Скоропадського) емігрував до Німеччини, де він з'явився на світ й дістав на чверть століття життєвий прихисток. Там же і похований наприкінці Другої світової війни. 


\section{Використані посилання}

Brucki J. 2000. Petlurowcy. Kraków, s. 600.

Верига В. 1998. Визвольні змагання в Украӥні. 1914-1923. У 2-х томах. Т. 1. Львів, с. 524.

Волков С. В. 2002. Белое движение. Энщиклопедия гражданской войныл. Санкт-Петербург; Москва, с. 672.

Державний вістник. 1918. Київ, 22 жовтень 1918, с. 1.

Задунайський В. 2003. Вплив козацьких військових традицій на ставлення Збройних сил Української держави гетьмана П. Скоропадського. Історичні і політичні дослідження. Донецьк, № 3-4, С. 98-104.

Кравчук М. 1997. Правові основи будівництва Національних Збройних Сил України в 1914-1993 рр. Івано-Франківськ, с. 292.

Кривизюк Л. 2006. Збройні сили України 1917-1920 pр. Вишкіл і виховання. Львів, с. 313.

Крип'якевич І., Гнатович Б., Стефанів 3. 1992. Історія українського війська. Львів, с. 702.

Литвин М., Науменко К., 2007. Збройні Сили Украӥни XX cm. Генерали та адмірали. Харків; Львів, с. 278.

Литвин В. 2003. Україна: доба війн і революиій (1914-1920). Київ, с. 413.

Монкевич Б. 1995. Організація армії Української Держави 1918 р. Україна в минулому. К.; Львів, Випуск 7, с. 67-112.

Науменко К. 2001. Юность командиров. Хабаровск; Львов; Москва, с. 112.

Скоропадський П. 1995. Скоропадський Павло. Спогади. Кінець 1917 - грудень 1918. Київ; Філадельфія, с. 443.

Україна: хроніка XX століття. Довідкове видання. Рік 1918. 2005. Київ, с. 402.

Ульяновський В. 1997. Церква в Українській державі (Доба Гетьманату Павла Скоропадського). Київ, с. 313.

ЦДАВО Украӥни, ф. 1074, оп. 2, спр. 7, арк. 37а.

Якимович Б. 1996. Збройні сили Украӥни. Нарис історії. Львів, c. 359.

\section{REFERENCES}

Brucki J. 2000. Retlurowcy. Kraków, s. 600 (pol).

Veriga V. 1998. Liberation competition in Ukraine. 1914 - 1923. In 2 volumes. T. 1. Lviv, p. 524 (ukr). 
Volkov S.V. 2002. White Movement. Encyclopedia of Civil War. St. Petersburg; Moscow, p. 672 (ukr).

State Newswire. 1918. Kiev. 22 October 1918. p. 1 (ukr).

Zadunaysky V. 2003. Effect of the Cossack military traditions on the attitude of the Ukrainian Armed Forces Hetman P. Skoropadsky. Historical and political studies. Donetsk, № 3-4, pp. 98 - 104 (ukr).

Kravchuk M. 1997. Legal framework for the construction of the National Armed Forces of Ukraine in 1914 - 1993. Ivano-Frankivsk. p. 292 (ukr).

Kryvyzyuk L., 2006. Armed Forces of Ukraine 1917 - 1920. Education and upbringing. Lviv, p. 313 (ukr).

Krypyakevych I., Gnatovych B., Stefaniv S. 1992. History of the Ukrainian army. Lviv, p. 702 (ukr).

Lytvyn M., Naumenko K. 2007. Armed Forces of Ukraine of the XX century. Generals and Admirals. Kharkiv; Lviv, p. 278 (ukr).

Lytvyn V. 2003. Ukraine: the era of wars and revolutions (19141920). Kyiv, p. 413 (ukr).

Monkevych B. 1995. Organization of the Army of the Ukrainian State in 1918 Ukraine in the past. K.; Lviv, Issue 7, pp. 67 - 112 (ukr).

Naumenko K. 2001. Youth of the commanders. Khabarovsk; Lviv; Moscow, p. 112 (rus).

Skoropadskiy P. 1995. Skoropadskiy Pavlo. Memoirs. End of 1917 - December 1918. Kiev; Philadelphia, p. 443 (ukr).

Ukraine: A Chronicle of the Twentieth Century. Reference edition. Year 1918, 2005. Kyiv, p. 402 (ukr).

Ulyanovskyi V. 1997. Church in the Ukrainian state (Date of Hetmanate of Pavlo Skoropadsky). Kyiv, p. 313 (ukr).

TsDAVO of Ukraine, f. 1074, op. 2, sp. 7, arch. 37a (ukr).

Yakymovych B., 1996. Armed Forces of Ukraine. Essay story. Lviv, p. 359 (ukr).

\section{Tkachuk P.}

Military reforms of hetman Pavlo Skoropadskyi in the context of processes of state development in Ukraine (April-December 1918)

The military reforms of hetman Pavlo Skoropadskyi in the context of processes of state development in Ukraine have been analyzed. The period is pointed out to be quite significant for developing a national regular force; though, in 1918 there were no chances for force 
development because of the German rule and also there was an offer to federate Ukraine with the other parts of non-Soviet Russia, which was supported by Cadet and October government of Ukraine. A political stance of ministers and cadets proved that the recognition of the independence of Ukraine was contextual (except for the head of the government Lyzohub who was an Octobrist) as a required stage for a federate, parliamentary or monarchical Russia.

It is established that Skoropadskyi succeeded in obtaining the permission for developing numerous Ukrainian Forces such as careeroriented corps, divisions which included gun brigades, engineering units with the officer and sergeant personnel and equipment. This stage of the force development was special because there was a planned organization at a high level in accordance with the developed organizational structures.

It was admitted that unlike «The Tsentralna Rada», hetman focused on developing a capable regular army with involving experienced generals, admirals, and senior officers of a former imperial army, who were willing to serve Ukraine. It was proved that though there were a plenty of enlisted generals who were not committed statists, they stayed in the army because it was the way to provide for a family or because of a professional need «to serve».

The Russian system was taken as a base for organizing the land forces of the Ukrainian Army and their kinds of armament, particularly the armament control system which was renewed and implemented starting from the Chief inspecting officers of infantry, artillery and mounted troops to commanders of corps, divisions of brigades and regiments. After coming back from battlefield to the base, 15 gun brigades joined the Ukrainian Army, except for most demobilized soldiers. The Serdiutska dismounted division was organized and Sira dismounted division was entirely preserved. Also, there was restored the function of infantry, artillery and a horse cavalry school and cadet corps. To conclude, thanks to hetman ruling the bases for developing Ukrainian Armed forces were established which in organization, structure, commanders, armament and tactics reached the same level of development as the European armies.

Keywords: Pavlo Skoropadskyi, Ukraine, military reforms, Armed Forces. 